\title{
Kuasa disiplin dalam kepemimpinan di perpustakaan (studi kasus kepala perpustakaan Sekolah Sukma Bangsa Lhokseumawe)
}

\author{
Najmi Fuady \\ Akademisi Prodi Ilmu Perpustakaan dan Informasi UIN Antasari Banjarmasin \\ e-mail:najmifuady@gmail.com
}

\begin{abstract}
Introduction. The purpose of this research is to analyze and describe the power that occurs in leadership in the library. This research is important because dismantling the rules for library staff is not only a disciplinary practice, but as a form of power reflected by the head of the library.

Data Collection Method. Qualitative research. Data was collected through in-depth interviews with the Head of School Library of Sukma Bangsa Lhoksumawe. The validity of the data is tested using data triangulation techniques.

Analysis Data. Analyzed using the theory of disciplinary power of Michel Foucault by looking at five things, namely: panopticsm, separation of places, documentation, standardization of judgments and rewards.

Results and Discussion. The form of power that occurs is supervision of hierarchy and standardization of judgments that are manifested in verbal rules about break time, whiteboard (work programs), separation of distance between work desks, differences in table shape, daily performance blanks, work standards, verbal reprimands and praise and gratitude.

Conclusions. Power runs productively and smoothly so staff don't realize it. In this study, i only describe how the power is realized and distributed by the head of the library through the rules. For further research you can take from the staff "how" they receive the power and they live it.
\end{abstract}

Keywords: Disciplinary power, Power form, Docile bodies, Rules, Library.

\begin{abstract}
ABSTRAK
Pendahuluan. Tujuan penelitian ini adalah untuk menganalisis dan mendeskripsikan kuasa yang terjadi di dalam kepemimpinan di perpustakaan. Penelitian ini penting karena membongkar tata aturan untuk staff perpustakaan bukan hanya sebagai sebuah praktik pendisiplinan, melainkan sebagai bentuk kuasa yang direfleksikan oleh kepala perpustakaan.

Metode Penelitian. Penelitian kualitatif. Data dikumpulkan melalui wawancara mendalam terhadap Kepala Perpustakaan Sekolah Sukma Bangsa Lhoksumawe. Data diuji keabsahannya menggunakan teknik triangulasi data.

Data Analisis. Dianalisis menggunakan teori disciplinary power atau kuasa disiplin Michel Foucault dengan melihat pada lima hal yaitu: panoptisisme, pemisahan tempat, dokumentasi, standarisasi penilaian dan ganjaran.

Hasil dan Pembahasan. Bentuk kuasa yang terjadi adalah pengawasan hierarki dan standarisasi penilaian yang diwujudkan dalam aturan verbal tentang waktu istirahat, whiteboard proker (program kerja), pemisahan jarak antar meja kerja, perbedaan bentuk meja, blanko kinerja harian, standar kerja, teguran verbal dan pujian serta rasa terimakasih.

Kesimpulan dan Saran. Kuasa berjalan secara produktif dan halus sehingga tidak disadari oleh staff. Dalam penelitian ini peneliti hanya menggambarkan bagaimana kekuasaan itu diwujudkan dan didistribusikan oleh kepala perpustakaan melalui tata aturan. Untuk penelitian selanjutnya bisa mengambil dari sisi staff "bagaimana" kuasa tersebut mereka terima dan mereka jalani.
\end{abstract}

Kata Kunci: Kuasa disiplin, Bentuk kuasa, Tubuh yang patuh, Tata aturan, Perpustakaan. 


\section{A. PENDAHULUAN}

Kepemimpinan sangat besar signifikansinya atas keberhasilan suatu organisasi. Melyn dan Roy (Rosintan and Setiawan 2014) mendefinisikan kepemimpinan lebih kepada kemampuan seseorang dalam mempengaruhi orang lain atau suatu kelompok dalam organisasi untuk mencapai tujuan tertentu. Keberhasilan atau kegagalan organisasi banyak ditentukan oleh kepemimpinan. Sebab kepemimpinan pada umumnya berfungsi berdasarkan kekuatan pemimpin untuk mempengaruhi, mendorong, dan menggerakan orang lain secara bersama-sama mencapai tujuan organisasi. Dari sini bisa terlihat bahwa di dalam kepemimpinan terdapat kekuasaan yang turut mengendap di dalamnya.

Mengenai kekuasaan ini, Michel Foucault telah banyak memberikan pandangannya. Misalnya Foucault dalam Ritzer dan Goodman (2017) menjelaskan bahwa antara kekuasaan erat kaitannya dengan pengetahuan dan antar keduanya itu saling mempengaruhi. Kekuasaan akan melahirkan pengetahuan dan pengetahuan akan menghasilkan kekuasaan dan akhirnya akan menguatkan posisi seorang pemimpin.

Konsep seperti ini tidak terbatas terjadi pada lingkungan makro seperti raja dan rakyat, namun juga disetiap institusi atau organisasi yang lebih kecil seperti perpustakaan. Dalam genealogi kekuasaanya, Foucault memusatkan perhatian tentang bagaimana orang mengatur dirinya dan orang lain melalui produksi kekuasaan. Di perpustakaan, kita bisa melihat adanya pengetahuan yang dibangun oleh kepala perpustakaan guna membangun kekuasaan dengan menjadikan staffnya sebagai subjek dan selanjutnya mengatur mereka dengan pengetahuan tadi. Foucault dalam Ritzer dan Goodman (2017) tertarik pada teknik ini, teknik yang berasal dari pengetahuan dan bagaimana mereka digunakan oleh seseorang untuk menjalankan kekuasaanya atas orang lain.

Penelitian sebelumnya yang pernah mengangkat topik kuasa dan perpustakaan adalah tesis dari saya sendiri yang berjudul "Mekanime Pendisiplinan Dalam Layanan Peminjaman Buku di Perpustakaan (Studi Kasus Keterlambatan Pengembalian Buku di Perpustakaan UIN Sunan Kalijaga Yogyakarta)" (Fuady 2019). Boleh jadi, artikel ilmiah ini merupakan kelanjutan dari kegelisahan akademik dari tesis yang pernah saya teliti sebelumnya. Pada penelitian lalu, saya mengangkat topik mengenai fenomena kuasa yang terjadi dalam relasi antar perpustakaan dengan pemustaka. Bahwa di dalam pengelolaan perpustakaan, adalah wajar perpustakaan memiliki tata aturan yang harus dijalani oleh pemustaka saat mereka meminjam buku, mulai dari menempatkan pemustaka yang ingin meminjam buku ke lantai tiga di ruang sirkulasi hingga melakukan pengawasan melalui denda. Namun alih-alih hanya dijalankan sebagai sebuah prosedur, saya melihat tata aturan peminjaman buku adalah usaha perpustakaan guna mendominasi serta menguasai tubuh pemustakanya agar tercipta tubuh pemustaka yang patuh dan disiplin. Bagi pemustaka sendiri, mereka tidak menyadari hal itu. Mereka hanya tahu bahwa hal tersebut adalah sebuah prosedur biasa saat mereka meminjam buku. Sehingga kekuasaan yang dioperasikan berjalan sangat halus dan lembut tanpa pernah disadari oleh pemustaka bahwa mereka sedang dikuasai oleh perpustakaan. Hal ini lantas memberikan pertanyaan kepada saya, jika relasi kuasa antara institusi dengan individu berjalan demikian, lalu bagaimana dengan relasi antara individu dengan individu lain dalam bingkai kepemimpinan dalam perpustakaan? bagaimana teknologi kuasa yang digunakan kepala perpustakaan terhadap staffnya agar staffnya mau tunduk dan patuh atas kuasanya guna menghasilkan kerjasama yang apik untuk menjalankan tujuan organisasi dengan baik?

Tujuan penelitian ini untuk mendapatkan gambaran yang komprehensif sekaligus melakukan analisis kritis terhadap bentuk kuasa yang diaplikasikan kepala perpustakaan kepada staffnya guna menciptakan tubuh yang patuh dan disiplin. Signifikansi penelitian ini adalah menguak bagaimana sebenarnya tata aturan yang diciptakan kepala perpustakaan kepada staff adalah sebuah produk kuasa guna menguasai dan mendominasi tubuh staffnya. 
Temuan yang terungkap diharapkan dapat menawarkan perspektif baru mengenai kekuasaan dari atasan kepada bawahan, lalu mengelola kekuasaan tersebut agar menjadi sesuatu yang positif dan berguna demi kemajuan organisasi. Kebanyakan penelitian yang sudah dilakukan hanya menguak relasi kuasa antara perpustakaan dengan pemustaka, dan pustakawan dengan perpustakaan. Originalitas penelitian ini bukan hanya terletak pada relasi kuasa yang berbeda (antara kepala perpustakaan dengan staff), melainkan juga mengungkap tata aturan yang tidak hanya berjalan sebagai sebuah prosedur kerja, namun sesungguhnya penuh dengan aspek politis dari kepala perpustakaan kepada staff perpustakaan.

\section{B. TINJAUAN PUSTAKA}

\section{Tinjauan Literatur}

Kajian literatur tentang fenomena kuasa di perpustakaan masih terbatas. Namun kajian mengenai kuasa dan praktik pendisiplinan pustakawan masih bisa ditemukan meski dengan kajian yang terpisah. Penelitian sebelumnya mengenai praktik kuasa oleh Misbah Mustofa (2017) dengan karya ilmiahnya di dalam jurnal yang berjudul "Analisis Disiplin dan Kuasa Tubuh Michel Foucault Dalam Kehidupan Santri Pondok Kebon Jambu Al-Islamy Pesantren Babakan Ciwaringin Cirebon". Penelitian ini bertujuan untuk menggambarkan bagaimana terjadinya proses relasi kuasa terkait dengan pendisiplinan tubuh yang ada dalam kehidupan Pondok Kebon Jambu Al-Islamy Pesantren Babakan Ciwaringin dengan menggunakan konsep disiplin tubuh dari Michel Foucault.

Objek penelitian adalah kegiatan serta kebijakan yang berlaku di Pondok Kebon Jambu Al-Islamy Pesantren Babakan Ciwaringin. Subjek penelitian adalah seluruh penghuni Pondok. Dari hasil penelitian ini ditemukan bahwa pendisiplinan tubuh yang ada di Pondok Kebon Jambu Pesantren Babakan Ciwaringin Cirebon terbentuk melalui beberapa konsep yang saling terbagi dan saling menguatkan, di antaranya adalah: pengawasan secara hierarki, normalisasi, dan terakhir adalah ujian.

Perbedaan dari penelitian dulu dengan penelitian sekarang tampak jelas pada lokasi penelitian dan objek pengamatan relasi kuasa yang terjadi. Penelitian dulu membahas pendisiplinan tubuh yang ada di pondok pesantren sedangkan penelitian sekarang ada di perpustakaan sekolah. Meskipun sama-sama menggunakan teori disciplinary power Michel Foucault, namun penelitian terdahulu melihatnya pada tatanan relasi kuasa antara pesantren dengan santri, sedangkan peneliti melihatnya dalam tatanan relasi antara kepala perpustakaan dengan staff.

Penelitian kedua yakni dari Baihaqi (2018) yang berjudul "Pengawasan Sebagai Fungsi Manajemen Perpustakaan Dan Hubungannya Dengan Disiplin Pustakawan". Penelitian ini merupakan penelitian literatur bertujuan untuk mengkaji pengawasan sebagai fungsi manajemen perpustakaan yang memiliki pengaruh signifikan terhadap disiplin pustakawan. Pengawasan oleh Baihaqi ternyata memiliki beragam jenis, metode, fungsi, dan tujuan yang gunanya untuk mendisiplinkan kerja pustakawan.

Pengawasan merupakan langkah yang dilakukan untuk mengetahui kesesuaian antara program yang dicanangkan dengan realisasi kegiatan. Terealisasinya sebuah program sangat bergantung kepada pelaksana program itu sendiri. Dalam lingkungan perpustakaan, pustakawan merupakan ujung tombak pelaksana kegiatan layanan perpustakaan. Dalam hubungannya dengan disiplin, tingginya disiplin kerja pustakawan dan pegawai perpustakaan tentunya tidak terlepas dari pengawasan yang dilakukan oleh atasan langsung yang meliputi, pemantauan, pemeriksaan, dan penilaian terhadap hasil kerja. Pengawasan merupakan suatu usaha yang sistematis untuk mengamati dan memantau berbagai fungsi, aktivitas dan kegiatan yang terjadi dalam pengelolaan perpustakaan sehingga sesuai dengan rencana yang ditetapkan. 
Di sisi lain, disiplin kerja ialah sikap menghormati, menghargai, patuh dan taat terhadap peraturan-peraturan yang berlaku, baik yang tertulis maupun tidak serta sanggup menjalankan dan tidak mengelak untuk menerima sanksi apabila melanggar tugas dan wewenang yang diberikan kepadanya. Dengan demikian, disiplin merupakan suatu akibat dari pengawasan yang dijalankan oleh pimpinan demi mencapai tujuan program yang telah direncanakan.

Meskipun tidak berupa studi kasus, penelitian yang dilakukan Baihaqi berguna bagi peneliti sebagai pijakan untuk memahami pentingnya aspek pengawasan dan pendisiplinan pustakawan di perpustakaan.

Penelitian selanjutnya oleh M. Hudhan Hakiki (2016) dalam jurnal yang berjudul "Makna Kuasa Pustakawan (Studi Kualitatif tentang Makna Kuasa Pustakawan di Badan Perpustakaan dan Kearsipan Provinsi Jawa Timur)". Tujuan penelitian ini adalah untuk mengetahui makna kuasa pustakawan di Bapersip Jatim dengan metode purposive sampling. Jumlah informan dalam penelitian ini sebanyak enam orang dengan kriteria tertentu. Dengan pendekatan kualitatif bertujuan agar peneliti bisa untuk mengetahui keadaan yang sebenarnya di lokasi penelitian dan mampu untuk menggali informasi yang lebih dalam melalui proses observasi dan wawancara mendalam (in-depth interview).

Hasil dari penelitian ini menunjukkan bahwasanya pustakawan yang bukan berasal dari lulusan perpustakaan cenderung untuk menurut pada yang memiliki kuasa yaitu pustakawan yang berasal dari lulusan perpustakaan dalam lingkup kerjanya. Seperti yang dikatakan oleh Foucault bahwasanya sebuah kuasa hanya akan berjalan dengan adanya pengetahuan dan juga pengetahuan akan selalu menghasilkan kuasa.

Meskipun sama-sama meneliti dalam ranah perpustakaan, namun perbedaan dari penelitian dulu dengan penelitian sekarang tampak jelas pada lokasi penelitian dan objek pengamatan relasi kuasa yang terjadi. Penelitian dulu membahas kuasa yang terjadi di Perpustakaan Bapersip Jatim sedangkan penelitian sekarang ada di perpustakaan sekolah. Meskipun sama-sama menjadikan kuasa sebagai objek, namun penelitian terdahulu melihatnya pada tatanan relasi kuasa antar pustakawan dengan pustakawan, sedangkan peneliti melihatnya dalam tatanan relasi antara kepala perpustakaan dengan staff. Penelitian yang dilakukan Hakiki akan berguna bagi peneliti untuk melihat bagaimana kepala perpustakaan memaknai hubungan kuasa yang terjadi dengan staffnya hingga akhirnya membuat semacam mekanisme untuk menjalankan kuasa atas mereka.)

\section{Tinjauan Teori}

\section{Perpustakaan Sekolah Sukma Bangsa Lhoksumawe}

Perpustakaan Sekolah Sukma Bangsa Lhoksumawe merupakan perpustakaan yang berada satu lingkungan dengan Sekolah Sukma Bangsa Lhoksumawe dan menjadi pusat sumber informasi bagi seluruh warga sekolah yang terdiri dari SD, SMP, SMA, Guru dan Non SDK dengan total seluruh pemustakanya berjumlah +/- 800 orang. Perpustakaan ini berada satu alamat dengan sekolahnya yakni di Jalan Medan-Banda Aceh Desa Panggoi Kecamatan Muara 2 Kota Lhoksumawe. Sampai saat ini, koleksi yang dimiliki perpustakaan adalah sebanyak 25.000 koleksi dan dikelola oleh dua orang, yakni kepala perpustakaan bernama Ernawati, S.Hum.,MA dan dibantu oleh satu orang staff yaitu Halimatun Sa'diyyah, S.Pd.

\section{Kepemimpinan}

Secara etimologi, Hasibuan (2007) menjelaskan bahwa kepemimpinan berasal dari kata dasar "pimpin" atau lead yang berarti bimbing atau tuntun. Secara istilah, kepemimpinan adalah kekuasaan untuk memengaruhi seseorang untuk mengerjakan atau 
tidak mengerjakan sesuatu. Untuk itu, oleh Umam (2018) kepemimpinan membutuhkan penggunaan kemampuan secara aktif untuk memengaruhi pihak lain dan dalam mewujudkan tujuan organisasi yang telah ditetapkan. Pemimpin menurut Robbins adalah seorang yang berkemampuan untuk mempengaruhi suatu kelompok kearah tercapainya tujuan. Selain itu, kepemimpinan merupakan proses pengaruh sosial yang mengikutsertakan bawahan dalam usaha pencapaian tujuan (Robbins 2003). Kesimpulannya, oleh Nurhayati (2016) kepemimpinan adalah suatu kemampuan dalam mengerahkan segenap kecakapan seseorang untuk memengaruhi, menggerakkan, membimbing, serta mengarahkan orang lain dengan memanfaatkan daya, dana, sarana, dan tenaga yang tersedia untuk mencapai tujuan tertentu.

Kepemimpinan erat kaitannya dengan kuasa. Karena dalam memengaruhi, menggerakkan, membimbing, serta mengarahkan orang lain dengan memanfaatkan daya, dana, sarana pastilah ada sisi penundukkan dan penguasaan baik fisik maupun non fisik kepada orang lain. Sekarang pertanyaanya adalah apakah kepemimpinan dan kuasa hanya terpusat pada institusi yang melibatkan hubungan antara pimpinan dan bawahan? jawabanya tidak mesti. Bahkan oleh Foucault, kuasa bisa dijalankan oleh siapa saja yang memiliki pengetahuan. Dalam konsepsinya tentang kuasa, kuasa itu menyebar, tidak terpusat pada seseorang atau institusi. Adlin (2016) menambahkan bahwa kuasa itu menyebar dalam hubungan-hubungan masyarakat, masuk kepada tatanan disiplin dan dihubungkan dengan jaringan, memberi struktur kegiatan-kegiatan, tidak represif tapi produktif, serta melekat pada kehendak untuk mengetahui. Namun dalam ranah organisasi seperti di perpustakaan, peneliti beragumen kuasa akan lebih kentara terlihat pada hubungan antara pimpinan dan bawahan yang oleh ini direfleksikan pada hubungan antara kepala perpustakaan dengan staff perpustakaan. Bagaimana seorang kepala perpustakaan meletakkan kuasa atas staffnya agar mau tunduk serta patuh merupakan cerminan dari kepemimpinan yang dimiliki oleh kepala perpustakaan tersebut.

\section{Kuasa Disiplin}

Kuasa disiplin adalah salah satu teknologi kuasa yang dijalankan individu, kelompok atau institusi untuk mendisiplinkan tubuh mereka yang dijadikan objek kuasa agar membuatnya menjadi tubuh yang patuh dan berguna (Hardiyanta 1997). Dalam kuasa disiplin, ada dua mekanisme yang harus dijalankan. Pertama adalah pengawasan hierarki atau kemampuan individu untuk mengawasi semua yang dia kontrol hanya dengan satu kali pengamatan. Kedua adalah kemampuan untuk melakukan penilaian yang menormalkan dan menghukum siapapun yang melanggar norma tersebut atau dalam hal ini disebut dengan normalisasi (Michel Foucault 1995). Individu bisa dinilai berperilaku negatif dan dihukum berdasarkan dimensi waktu (karena terlambat), aktivitas (karena tidak memerhatikan), dan perilaku (karena tidak sopan).

\section{Pengawasan Hirarki}

Dalam hal ini Foucault menjelaskan bahwa pendisiplinan dapat dibentuk melalui pengawasan hierarki atau pengawasan bertingkat. Prinsip dari pengawasan ini yaitu invisible di mana individu sadar bahwa dirinya sedang diawasi namun dia tidak bisa melihat di mana pengawas itu berada. Bagi para pengawas (atau pemilik kuasa, pemilik kepentingan) mekanisme ini mampu membuat dirinya melihat akibat kuasa yang dilaksanakannya tanpa bisa dilihat oleh objek yang dikenakan kuasa. Dengan begini, maka oleh Hardiyanta (1997) dikatakan efek pengawasan bisa berjalan secara otomatis tanpa dilakukan pengawasan setiap saat, setiap waktu. Untuk menjalankan model pengawasan seperti ini dibutuhkan tiga macam instrumen yaitu panoptisisme, pembagian tempat dan dokumentasi. 


\section{1) Panoptisisme}

Panoptisisme merupakan istilah untuk merujuk kepada sebuah cara kerja penjara bernama panoptikon. Panoptikon merupakan desain penjara yang dikenalkan oleh Jeremy Bentham lalu diadopsi Foucault untuk mengkonsepsikan teori kuasa disiplin yang dia bangun (Michel Foucault 1995). Panoptikon merupakan penjara berbentuk lingkaran yang ditengahnya terdapat menara pengawas guna memberikan sipir penglihatan yang sangat jelas ke semua sel. Dengan desain seperti ini membuat kekuasaan semakin kuat dan mengakar karena para tahanan akan mengontrol tubuh mereka sendiri secara otomatis; mereka menghentikan diri mereka sendiri agar tidak melakukan pelbagai hal yang mencurigakan karena sadar bahwa mereka berada diposisi yang sangat mudah terlihat oleh penjaga atau sipir (Ritzer and Goodman 2017). Prinsip merasa terus terawasi ini lalu disebut dengan panoptisisme.

2) Pembagian Tempat

Setelah panoptisisme tertanam, selanjutnya membagi ruang menjadi ruang-ruang yang lebih kecil. Pembagian ruang-ruang kecil ini oleh Foucault (1995) dimaksudkan untuk meningkatkan efektifitas pengawasan serta lebih memfokuskan individu untuk memberdayakan orang lain.

3) Dokumentasi

Setiap informasi yang dihasilkan dari individu akan didokumentasikan. Hal ini diperlukan untuk memantau perkembangan individu dan sebagai bahan pengambilan keputusan untuk para pemilik kuasa. (Hardiyanta 1997)

\section{Normalisasi}

Mekanisme selanjutnya yakni normalisasi atau standarisasi penilaian. Normalisasi merupakan bagian dari kuasa disiplin yang berguna untuk mengukur, mengelompokan, dan mengategorikan individu sesuai standar atau norma tertentu. Untuk menjalankan normalisasi dilakukan dengan dua instrumen, yakni standarisasi penilaian dan ganjaran.

\section{1) Standarisasi Penilaian}

Standarisasi penilaian adalah sebuah acuan atau panduan atas prestasi baik dan buruk yang diperoleh individu. Kehadiran standarisasi ini nantinya akan memaksa individu membentuk kedisiplinan dalam dirinya dan akan berusaha bertindak sesuai dengan standar yang sudah ditetapkan. Jika usahanya keras maka oleh Martono (2014) dikatakan kualitas dirinya akan berada diatas standar, jika tidak maka dia akan berada di bawah.

\section{2) Ganjaran}

Setelah standarisasi penilaian dibuat maka yang selanjutnya dilakukan adalah memberikan ganjaran. Individu yang mampu mencapai standar yang ditetapkan akan mendapatkan hadiah, apabila tidak mencapai maka akan diberikan hukuman. Ini dilakukan untuk memotivasi individu untuk dapat memenuhi standar tersebut. Namun yang perlu diperhatikan oleh Hardiyanta (1997) adalah bahwa hukuman yang diberikan harus tetap mengacu pada dua hal yakni mengoreksi dan melatih agar mampu menciptakan sesuatu yang positif dan berguna. Untuk memberikan gambaran yang lebih jelas, sila simak pada tabel berikut: 
Tabel 1. Objek Pengamatan Disciplinary Power (Foucault, 1979)

\begin{tabular}{|l|l|l|}
\hline $\begin{array}{c}\text { Mekanisme Kuasa } \\
\text { Disiplin }\end{array}$ & \multicolumn{1}{|c|}{ Pengawasan Hierarki } & \multicolumn{1}{c|}{ Normalisasi } \\
\hline Objek Pengamatan & $\begin{array}{l}\text { 1. Panoptisisme } \\
\text { 2. Pemisahan Tempat }\end{array}$ & $\begin{array}{l}\text { 1. Standarisasi Penilaian } \\
\text { 3. Dokumentasi }\end{array}$ \\
& & \\
\hline
\end{tabular}

\section{METODE PENELITIAN}

Penelitian ini mengkaji tentang bentuk kuasa yang dihasilkan kepala perpustakaan terhadap staffnya agar staffnya mau tunduk dan patuh atas kuasanya guna menghasilkan kerjasama yang apik untuk menjalankan tujuan organisasi dengan baik.

Perpustakaan Sekolah Sukma Bangsa Lhoksumawe dipilih sebagai lokasi penelitian. Perpustakaan ini dipilih karena melayani tiga sekolah sekaligus yakni SD, SMP dan SMA yang mana dari asumsi saya untuk menjalankan perpustakaan dengan pemustaka sebanyak itu perlu keuletan, kerjasama dan komunikasi yang baik antara kepala dan staff perpustakaannya. Objek sekunder dalam penelitian ini adalah Kepala Perpustakaan Sekolah Sukma Bangsa Lhoksumawe sedangkan yang menjadi objek primer ialah tata aturan yang dikeluarkan oleh kepala perpustakaan untuk dipatuhi staffnya.

Pemilihan kedua objek (primer dan sekunder) saya lakukan atas dasar untuk memberikan keakuratan data. Dalam bukunya, Nurdin Laugu (2015) menjelaskan agar peneliti memperoleh otoritas yang penuh atas data yang hendak diperoleh, maka objek penelitian harus dibagi mejadi dua yakni objek primer dan objek sekunder. Objek primer yaitu persoalan utama yang diteliti dan objek sekunder yaitu sumber data. Lalu yang berperan sebagai subjeknya ialah peneliti sendiri.

Pengumpulan data dilakukan melalui wawancara mendalam kepada objek sekunder (Kepala Perpustakaan Sekolah Sukma Bangsa Lhoksumawe, Ernawati, S.Hum pada tanggal 16 Januari 2019) untuk digali informasi mengenai objek primernya. Untuk menguji kevalidan data, digunakan triangulasi data dengan cara mengecek kembali data-data yang didapat melalui wawancara mendalam, mengecek kembali data dari informan melalui teknik yang berbeda dan mengecek kembali informasi yang didapatkan dalam waktu yang berbeda. Analisis data dilakukan dengan metode kualitatif hingga menjadikan penelitian ini berjenis penelitian kualitatif.

Untuk menguak kuasa yang tercermin dalam relasi kuasa antar kepala perpustakaan dengan staff, saya menggunakan teori disciplinary power atau kuasa disiplin dari Michel Foucault. Kuasa disiplin memiliki dua mekanisme untuk menjalankan kekuasaan yakni pengawasan hierarki dan normalisasi yang mana dari dua mekanisme ini terdapat lima instrumen yang akan digunakan sebagai objek pengamatan dalam penelitian ini yakni panoptisisme, pemisahan tempat, dokumentasi, standarisasi penilaian dan ganjaran. Semua hasil analisis data akan ditampilkan dengan menggunakan pendekatan desktriptif.

\section{HASIL DAN PEMBAHASAN Pengawasan Hirarki}

Pengawasan hierarki merupakan mekanisme pendisiplinan yang tugasnya adalah mengawasi individu. Yang unik dari mekanisme ini adalah sang objek kuasa tidak menyadari bahwa dia sedang diawasi dan dipantau perilakunya. Kepala perpustakaan dalam hal ini akan 
memberikan suatu kebijakan, perintah maupun peraturan yang mana hal itu disebarkan kepada staff perpustakaannya untuk ditaati dan dipatuhi. Melalui mekanisme ini, kepala perpustakaan akan melatih, memaksa, menandai, membentuk, menanamkan dan menguasai tubuh staff secara elegan dengan tanpa dia sadari bahwa sedang berada di bawah kuasa kepala perpustakaan.

\section{Panoptisisme}

Seperti yang dijelaskan sebelumnya salah satu objek pengamatan dari pengawasan hierarki adalah panoptisisme. Panoptisisme ditanamkan ke diri staff melalui transfer power of knowledge dalam bentuk peraturan dan kebijakan baik verbal dan non verbal yang diproduksi oleh kepala perpustakaan. Foucault dalam Ritzer dan Goodman (2017) menjelaskan bahwa dengan power of knowledge ini individu membangun kekuasaan dengan menjadikan individu lain sebagai objek kuasa dan selanjutnya mengaturnya dengan pengetahuan yang dimilikinya. Hal ini lantas akan membuat kekuasaan yang dibangun mengendap dalam diri objek kuasa, masuk mencapai bagian terdalam diri mereka, merasuk ke dalam tindakan, tingkah laku, wacana, dan proses belajar serta kehidupan sehari-hari sampai mereka tidak menyadari bahwa mereka sedang berada dalam pengaruh kuasa orang lain (Mitchel Foucault 2002). Contohnya pada saat jam istirahat kepala perpustakaan akan melakukan negosiasi dengan staff mengenai pembagian waktu meninggalkan perpustakaan. Waktu tersebut dibagi per satu jam. Jika kepala perpustakaan meninggalkan ruang kerja pada jam 12 - 13 siang, maka staff harus tetap stand by di perpustakaan agar perpustakaan tidak kosong. Jika sudah memasuki jam 13 - 14 siang, kepala perpustakaan akan kembali lagi untuk berganti giliran dengan staffnya. Dan durasi waktu istirahat ini sudah disepakati di awal. Simak hasil wawancara sebagai berikut.

"Apakah mbak punya peraturan kepada staff perpustakaan? misal jam datang, pergi atau istirahat?"

- Kalau peraturan, itu disamakan dengan peraturan sekolah baik itu datang dan pergi. tapi Saya dengan Atun bisa bernegosiasi diwaktu istirahat. Kita biasanya bergantian, misalkan Saya duluan istirahat, Atun yang tetap tinggal di perpustakaan. kalau Saya sudah selesai, lalu bergantian.

Dari aturan verbal ini kita bisa melihat kepala perpustakaan sedang melakukan transfer power of knowledge berupa aturan durasi waktu istirahat untuk membangun panoptisisme atas staffnya. Aturan ini disampaikan melalui dialog. Melalui aturan verbal ini, kepala perpustakaan meletakkan kuasa dalam bentuk pengawasan dan pemantauan kepada staffnya hingga membuat staffnya selalu ingat bahwa jam istirahat adalah antara jam $12-14$ siang dengan durasi hanya satu jam dan harus bergantian. Karena panoptisisme disampaikan melalui dialog secara langsung maka mau tidak mau staff perpustakaan harus mematuhi apa yang telah disepakati sehingga dia tidak bisa untuk melanggar aturan tersebut, meskipun memang hal itu bisa saja terjadi, namun panoptisisme yang sudah dibangun diawal oleh kepala perpustakaan secara refleks akan menghalanginya untuk melanggar aturan tersebut.

Kemudian yang kedua adalah bahwa panoptisisme yang mewujud pada aturan verbal yang disampaikan oleh kepala perpustakaan tadi membuat mekanisme pengawasan dan pemantauan bekerja secara otomatis. Artinya tanpa kepala perpustakaan memperlihatkan diri di hadapan staff perpustakaan setiap waktu, aturan verbal yang sudah ditanam tadi di dalam kesadaran staff perpustakaan sudah menjadi refleksi diri dari kepala perpustakaan itu sendiri sehingga membuat staff perpustakaan seakan-akan terus merasa diawasi dan diamati meski tanpa kehadiran wujud fisik dari kepala perpustakaan di sekitarnya.

Selain aturan verbal untuk durasi waktu istirahat kerja. Kepala perpustakaan juga sering menanamkan panoptisisme kepada staff perpustakaannya melalui power of knowledge berupa ketentuan pekerjaan yang harus dikerjakan. Panoptisisme ini dibangun 
sebagai pengingat bahwa staff perpustakaan sedang dibebani sebuah pekerjaan dan dia harus menyelesaikan pekerjaan tersebut hingga batas yang ditentukan. Sama dengan aturan verbal durasi istirahat kerja, aturan verbal kali ini juga dilakukan diawal saat kepala perpustakaan memberikan perintah kerja. Simak hasil wawancara sebagai berikut.

"Dalam memberikan pekerjaan, di tengah waktu yang diberikan apakah mbak ada juga memberikan semacam pengingat kepada dia untuk tetap mengerjakan pekerjaan sesuai dengan yg diinginkan?"

- Tidak ada. Karena begitu disampaikan di awal, sudah sesuai aturan mainnya. Misalkan deadline nya seminggu, si Atun akan mengerjakan deadline itu selama seminggu tanapa harus kita ingatkan lagi.

"Jadi gak ada pengingat lagi ditengah-tengah? atau lewat di sms, misal?"

- Tidak ada. Karena hampir tiap hari ketemu secara intens. Selain itu kita punya papan putih informasi yang mendeskripsikan tentang apa perkerjaan si Atun yg harus dia selesaikan.

Untuk membantu agar aturan verbal pekerjaan tadi bisa terus diingat dan menguatkan panoptisisme atas staffnya, kepala perpustakaan juga menyediakan semacam whiteboard proker (program kerja) yang ditempel di dinding sekitar ruang kerja staff perpustakaan. Hal ini berisi informasi tentang pekerjaan dan waktu pekerjaan yang harus diselesaikan. Hal ini berguna sebagai pengingat agar staff perpustakaan tidak lupa dengan pekerjaanya dan juga kapan pekerjaan itu harus diselesaikan olehnya. Setiap kali staff masuk ke ruang kerja, whiteboard proker ini akan terus dilihatnya dan hal ini akan membangkitkan ingatannya akan sebuah pekerjaan yang harus diselesaikan. Maka secara tidak langsung, tanpa dia sadari dia telah berada di bawah kuasa kepala perpustakaan.

\section{Pemisahan Tempat}

Dalam menerapkan pengawasan hierarki, kepala perpustakaan juga memperketat kontrol aktivitas dan perilaku staffnya dengan cara menata letak meja kerja. Usaha ini dilakukan agar pengawasan mudah dilakukan serta efisien. Staff akan berfikir dua kali jika ingin keluar tanpa izin karena dia merasa bahwa selalu diperhatikan oleh atasan. Untuk datang terlambat pun staff perpustakaan akan merasa malu karena bisa dilihat secara langsung oleh atasan kedatangannya. Simak hasil wawancara sebagai berikut.

"Apakah diruang kerja ada pemisahan tempat?"

- Ada. Kami tetap dalam satu ruang namun berpisah meja. Misalnya seperti huruf $U$ gitu. Si Atun (staff perpustakaan) itu duduknya didepan (bagian pelayanan) lalu dibelakangnya itu Saya dengan meja khusus. Meja Saya lebih besar dari meja karyawan, kemudian juga ada papan nama Saya sebagai kepala perpustakaan, dan memiliki fasilitas seperti komputer lcd dan printer diatasnya. Kemudian di atas meja Saya dilapisi dengan kaca. Kalau staff meja nya lebih kecil, tidak ada lapisan kaca, tetapi juga ada komputer dan printer namun tidak sebesar dan secanggih punya Saya.

Selain itu dari pemisahan tempat ini saya juga menilai bahwa kepala perpustakaan menyelipkan pesan yang sangat halus kepada staff bahwa yang memiliki kuasa atas dirinya dan perpustakaan secara keseluruhan adalah dia, kepala perpustakaan. Ini bisa dilihat dari pengaturan meja yang khusus dibuat berbeda untuk kepala perpustakaan yang mana meja tersebut berada di belakang meja staff, lebih besar, lalu ditambahkan lapisan kaca diatasnya, memiliki komputer LCD serta printer dan memiliki papan nama kepala perpustakaan di atas meja tersebut.

Pemisahan tempat seperti ini semakin menguatkan kuasa dari kepala perpustakaan kepada staffnya. Citra yang ditampilkan dari pemisahan tempat merupakan citra pimpinan - 
bawahan dan hal ini hampir tiap hari dilihat oleh staff perpustakaan sehingga membuatnya merasa bahwa ada keharusan untuk menaruh hormat serta tunduk dan patuh kepada atasannya.

\section{Dokumentasi}

Dokumentasi diperlukan untuk mengawasi sejauh mana kinerja dari staff perpustakaan. Dari dokumentasi juga kepala perpustakaan bisa melihat kekurangan kinerja staff perpustakaannya lalu berdiskusi untuk mememecahkan persoalan tersebut. Seperti yang terlihat dari kebijakan blanko kinerja yang dikeluarkan oleh kepala perpustakaan. Blanko ini juga berfungsi sebagai absensi kehadiran untuk staff di perpustakaan. Simak hasil wawancara sebagai berikut.

"Jika finger print berlaku di lingkungan keseluruhan sekolah, kalau di perpustakaan sendiri ada sistem absen juga mbak?"

- Kalau di perpustakaan itu dia ada blanko laporan kinerja namanya. Tiap kali dia datang dia harus mengisi blanko itu mengenai apa aja yang dikerjakan dsb. Jadi Saya menyiapkan blanko, jadi dia catat secara manual dan nantinya akan diinput ke sintaka, seperti software yang khusus mencatat aktifitas tenaga pengelola perpustakaan. Jadi disana terlihat dia kerjanya apa saja. Kalau ternyata kerjaanya itu-itu saja, nanti akan kita evaluasi.Bbisa nanti kita beri ritme kerja yang berbeda. Misalnya Saya tambahkan kerja shelving atau memberi informasi mengenai keterlambatan siswa dalam mengembalikan buku ke kelas-kelas.

- Ritme kerjanya ada yang tetap dan ada yang fleksibel.

Melalui blanko kinerja, staff perpustakaan diatur dan diawasi kegiatannya selama satu hari penuh oleh kepala perpustakaan. Mulai dari waktu datang, hingga pulang. Semua kegiatan yang dilakukan harus dicatat dalam blanko ini. Melalui cara ini, pengawasan dilakukan secara otomatis hingga nantinya membentuk pribadi yang disiplin dan patuh. Sebagaimana yang dikatakan Foucault, disiplin dapat menyentuh tubuh dari berbagai kontrol aktivitas yang dicapai dengan cara pengaturan waktu, pembentukan ketepatan antara waktu dengan tindakan, penciptaan sikap tubuh yang efisien.

Setelah itu, tubuh dilatih untuk membentuk ketepatan tindakan dengan capaian. Hal ini dapat dilihat dalam blanko tersebut mengenai kerja apa saja yag sudah dilakukan dan hasil apa yang sudah dicapai. Jika kepala perpustakaan menemukan suatu pekerjaan yang tidak memiliki progress peningkatan atau pekerjaan yang tidak sesuai dengan kesepakatan awal, kepala perpustakaan akan melakukan dialog untuk sama-sama memecahkan permasalahan yang ada.

Melalui instrumen ini, akan menghasilkan ketepatan sikap tubuh dalam melakukan suatu tindakan tertentu. Staff perpustakaan dituntut untuk memanfaatkan waktunya dengan baik, mengisi tiap waktu di perpustakaan dengan kerja-kerja yang produktif. Disini tubuh staff perpustakaan dilatih untuk menemukan sikap yang tepat bagi suatu aksi atau tindakan sehingga penggunaan waktu bisa lebih efektif dan efisien.

Akhirnya kita bisa melihat bahwa tubuh ditaklukan dengan rezim pengawasan hierarki oleh Kkepala perpustakaan. Melalui pengawasan ini, yang dalam hal ini mewujud pada blanko kinerja, maka terjadilah penaklukan kuasa atas staff perpustakaan. Melalui cara ini dibentuklah suatu objek baru dari kuasa, yakni tubuh yang terlatih dan berguna.

\section{Normalisasi}

Normalisasi merupakan mekanisme dari kuasa disiplin selanjutnya yang menjadi mekanisme penilaian untuk mengukur, mengelompokan, dan mengategorikan individu sesuai standar atau norma tertentu. Pada intinya normalisasi ini mewujud pada mekanisme 
hukuman kecil mengenai ketidaktepatan waktu, aktivitas dan tingkah laku sebagai sesuatu yang dapat menyadarkan individu menyadari telah melakukan suatu pelanggaran.

\section{Standarisasi Penilaian}

Standarisasi penilaian merupakan standar yang harus dicapai oleh staff perpustakaan atas perintah yang diminta oleh kepala perpustakaan. Standar ini berawal dari nego yang dilakukan mengenai kesanggupan si staff. Jika stafff merasa bisa melakukannya, maka pekerjaan bisa dikerjakan. Jika tidak, maka nego selanjutnya akan terjadi. Simak hasil wawancara sebagai berikut.

"apakah setiap pekerjaan yang mbak sampaikan diikuti dengan standar yang harus dicapai?"

- Ada, misalnya ada pekerjaan yg Atun sendiri tidak terbiasa. Kalau dia udah pernah, maka dia tidak bertanya lagi. Saya memberi perintahnya dalam bentuk pesan dan langsung. Kalau dari langsung, dia tidak akan bertanya lagi dan langsung dikerjakan. Kalau lewat pesan, dia biasanya akan bertanya lagi menemui Saya apakah pekerjaan yag dilakukan sudah sesuai dengan permintaan.

\section{Ganjaran}

Penerapan upaya normalisasi dalam konteks kuasa antara kepala perpustakaan dengan staff perpustakaan dapat dilihat dari beberapa ganjaran yang diberikan. Apabila staff tidak mampu bertindak (baik itu bersikap maupun mengerjakan suatu pekerjaan) sesuai dengan standar yang diberikan, maka akan diberikan hukuman. Apabila staff mampu mencapainya, maka akan diberikan semacam hadiah. Misalnya dalam kasus keterlambatan jam masuk. Simak hasil wawancara sebagai berikut.

- Kalau ada keterlambatan, data keterlambatan itu disampaikan oleh pusat data lalu disampaikan kepada kepalanya. Dalam hal ini bila Atun terlambat masuk, maka pusat data akan lapor ke Saya untuk Saya memberikan sangsi ke dia. Yang pertama Saya lakukan ialah menanyakan kepada dia mengapa bisa terlambat, tetapi karena dia anaknya humoris jadi kalau menjawab pertanyaan Saya itu tidak terlalu serius dan itu malah bisa meluluhkan hati Saya.

- Lalu apabila si Atun terlambat lagi, Saya akan memberinya teguran lisan terlebih dahulu

Mekanisme hukuman seperti ini berjalan dengan cara kekeluargaan dan persuasif. Peneliti melihat hal ini dikarenakan kepala perpustakaan tidak ingin merusak lingkungan kerja yang selama ini sudah berjalan dengan baik. Meskipun ada pencideraan atas kuasa kepala perpustakaan mengenai jam masuk, nyatanya disini telihat kepala perpustakaan tidak ingin berkompromi dengan hubungan kuasa yang sudah dia bangun kepada staff perpustakaannya. Apabila kepala perpustakaan memberikan hukuman yang terlampau berat, maka hal itu akan mencederai kekuasaan yang sudah terjalin karena bisa saja hal ini berlanjut dengan terlukanya hati si staff perpustakaan lalu memutuskan untuk berhenti bekerja.

Dari segi waktu hukuman bisa juga diberikan secara langsung ditempat. Misalnya ketika kepala perpustakaan menerima informasi bahwa staffnya datang terlambat dari pusat data, maka kepala perpustakaan langsung menanyakan hal itu kepada staff perpustakaanya dan bila masih melakukannya lagi akan diberikan teguran secaara lisan, itupun masih dalam lingkup kekeluargaan.

Dalam mekanisme hukuman ini, peneliti melihat efek yang ditimbulkan lebih kepada pengingat dan perasaan malu karena apabila staff perpustakaan tersebut terlalu sering terlambat datang, maka otomatis juga dia akan sering ditegur oleh kepala perpustakaan. Dan ini bila terus dilakukan, akan mengundang rasa malu yang berlebih. 
Mekanisme hukuman dan ganjaran ini tidak dibuatkan secara tertulis, melainkan hanya secara verbal atau lisan. Jadi, staff perpustakaan mau tidak mau harus selalu mengingat setiap aturan yang diproduksi oleh kepala perpustakaan kepada dirinya. Simak hasil wawancara sebagai berikut.

"Mengenai aturan, apakah aturan disampaikan secara tertulis atau lisan?"

- Tidak, peraturannya secara verbal saja. Kalau tertulis biasanya sudah ada di peraturan sekolah.

Setelah standarisasi penilaian diterapkan, dan apabila hasil kerja tidak sesuai dengan yang diingkan maka staff perpustakaan akan diberi hukuman teguran secara kekeluargaan. Apabila staff perpustakaan sukses mencapai standar yang diinginkan, maka ganjaran pun akan diberikan. Namun ganjaran yang diberikan tidak terkhusus pada materi, melainkan berupa pujian dan rasa terimakasih dari kepala perpustakaan kepada staff perpustakaannya. Simak wawancara sebagai berikut.

"Ganjaran apa yang biasanya mbak berikan jikalau staff perpustakaan mampu mengerjakan tugas yang mbak berikan dengan baik dan memuaskan?"

- Apresiasi dalam bentuk pujian. Kalau reward dalam bentuk benda biasanya saya traktir.

\section{E. PENUTUP \\ Kesimpulan}

Dari penelitian ini kita bisa melihat bagaimana kuasa kepala perpustakaan bekerja untuk mencetak tubuh staff yang patuh serta berguna melalui dua mekanisme yaitu pengawasan hierarki dan normalisasi. Kuasa disiplin ditanamkan oleh kepala perpustakaan menuju ke titik terdalam kesadaran staff perpustakaanya sehingga efek yg ditimbulkan adalah staff karyawan merasa tidak sedang dikuasai, melainkan seperti layaknya menjalani kegiatan dan kewajiban sehari-hari di perpustakaan.

Kuasa disiplin terlihat dari lima objek pengamatan yang ke semuanya terpenuhi, yaitu panoptisisme, pemisahan tempat, dokumentasi, standarisasi penilaian serta ganjaran. Panoptisisme ditanamkan melalui transfer power of knowledge dalam bentuk aturan verbal tentang waktu istirahat dan whiteboard proker (program kerja) yang diletakkan di dinding perpustakaan tidak jauh dari meja kerja staff. Pemisahan tempat diwujudkan dalam bentuk pemisahan jarak antar meja kerja staff dengan kepala dan juga bentuk meja kerja itu sendiri. Dokumentasi diwujudkan dalam bentuk blanko kinerja harian. Standarisasi diwujudkan dalam bentuk standar kerja yang disampaikan di awal dan untuk ganjaran berupa hukuman diwujudkan dalam bentuk teguran verbal atau lisan apabila standar kerja dicapai sesuai yang diinginkan maka ganjaran yang diberikan adalah hadiah dalam bentuk pujian serta rasa terima kasih.

\section{Saran}

Saya menyadari bahwa penelitian ini masih jauh dari kata sempurna. Tetapi setidaknya peneliti telah menawarkan sedikti cakrawala pengetahuan mengenai kuasa yang terjadi dalam bingkai kepemimpinan di perpustakaan. Untuk itu peneliti berharap agar penelitian ini bisa dijadikan landasan, atau minimal inspirasi guna dilakukan penelitian lanjutan tentunya dengan data atau analisis yang lebih update dan komprehensif demi kemajuan ilmu perpustakaan dan informasi khususnya pada bidang manajemen pengelolaan perpustakan dan sumber daya. 


\section{DAFTAR PUSTAKA}

Adlin, Alfathri. 2016. 'Michel Foucault: Kuasa/Pengetahuan, (Rezim) Kebenaran, Parrhesia'. Jurnal Aqidah dan Filsafat Islam 1 (1): 13-26.

Baihaqi. 2018. 'Pengawasan Sebagia Fungsi Manajemen Perpustakaan Dan Hubungannya Dengan Disiplin Pustakawan'. LIBRIA 8 (1). https://jurnal.arraniry.ac.id/index.php/libria/article/viewFile/1227/920.

Foucault, Michel. 1995. Discipline \& Punish: The Birth of the Prison. Translated by Alan Sheridan. New York: Vintage Books.

Foucault, Mitchel. 2002. Power / Knowledge : Selected Interviews and Other Writing 19721977. Edited by Yudi Sentosa. Yogyakarta: Bentang Budaya.

Hakiki, M. Hudhan. 2016. 'Makna Kuasa Pustakawan (Studi Kualitatif Tentang Makna Kuasa Pustakawan di Badan Perpustakaan dan Kearsipan Provinsi Jawa Timur)'.

Hardiyanta, Sunu. 1997. Michel Foucualt: Disiplin Tubuh Bengkel Individu Modern. Yogyakarta: LKIS.

Laugu, Nurdin. 2015. Representasi Kuasa Dalam Pengelolaan Perpustakaan. Yogyakarta: Gapernus Press.

Martono, Nanang. 2014. Sosiologi Pendidikan Michel Foucault. Jakarta: PT. Raja Grafindo Perkasa.

Mustofa, Misbah. 2017. 'ANALISIS DISIPLIN DAN KUASA TUBUH MICHEL FOUCAULT DALAM KEHIDUPAN SANTRI PONDOK KEBON JAMBU ALISLAMY PESANTREN BABAKAN CIWARINGIN CIREBON'. JURNAL YAQZHAN: Analisis Filsafat, Agama dan Kemanusiaan 3 (1). http://www.syekhnurjati.ac.id/jurnal/index.php/yaqhzan/article/view/2128.

Nurhayati, Tati. 2016. 'HUBUNGAN KEPEMIMPINAN TRANSFORMASIONAL DAN MOTIVASI KERJA'. Edueksos: Jurnal Pendidikan Sosial \& Ekonomi 1 (2). https://doi.org/10.24235/edueksos.v1i2.380.

Ritzer, George, and Douglas J Goodman. 2017. Teori Sosiologi. Edited by Nurhadi. Bantul: Kreasi Wacana.

Robbins, Stephen P. 2003. Perilaku Organisasi. Jakarta: Index.

Rosintan, Melyn, and Roy Setiawan. 2014. 'Analisis Gaya Kepemimpinan Perempuan Di PT. Ruci Gas Surabaya'. AGORA 2 (2): 1-11.

Umam, Khaerul. 2018. Perilaku Organisasi. 3. Jakarta: Pustaka Setia. 